\title{
A preliminary analysis of product-service system (PSS) types and implementation
}

\author{
Eduardo de Senzi Zancula, Paula Lubanco de Almeida Nobre ${ }^{a}$, Anderson de Carvalho Nakanishi", Britta Pergande \\ Leandro Lossc', Lucas Cley da Hortac', Fernanda Hänsch Beuren ${ }^{d}$, Paulo Augusto Cauchick Miguel ${ }^{d}$ \\ asão Paulo University \\ UUniversity of Bremen \\ 'Axia Value Chain \\ 'Federal University of Santa Catarina \\ e-mail: cauchick@deps.ufsc.br
}

\begin{abstract}
Companies have started offering solutions to increase their market position as well as their customers' satisfaction. One of the solutions is the inclusion of services to products, called Product-Service System (PSS). It is an integrated combination of products and services. In this sense, this paper aims at presenting a typology for PSS and an implementation approach. The proposed typology outlines different possible combinations of products with the corresponding services in order to achieve a PSS. The implementation approach defines the necessary steps for implementation and the details of which actions have to be performed in order to create and improve a PSS. Those two results should support companies when establishing a PSS including its expected benefits of that business model.
\end{abstract}

Keywords: product-service systems, PSS, service offering.

\section{Introduction}

Manufacturing companies have focused more and more on providing additional services for their existing products. They start offering solutions aiming at increasing their market position as well as customers' satisfaction (SUNDIN, 2009; SAKAO et al., 2009). One of the solutions being discussed is Product-Service System (PSS) as an integrated combination of products and services. A PSS provides manufacturing companies a platform to: (i) increase differentiation of its complete solution from the competition; (ii) support revenue growth beyond the limitations of pure-product market; (iii) establish stronger customer loyalty; (iv) create continued service revenue streams; and (v) manage the whole product life cycle, resulting in a more sustainable business model.

As this is a recent trend, there is still room for creating an approach for companies on how to implement a ProductService System (PSS) and enhance their service revenue stream. In this sense, the objective of this paper are to develop a typology of Product-Service Systems, considering possible combinations of different product and service types. In addition, it also aims at presenting the basis for an implementation approach (at a preliminary level) to guide product-based manufacturing companies to build and improve PSS. The paper is structured in six sections.
Following this one, section 2 presents research methods and section 3 outlines the state of the art in Product-Service Systems types and implementation. The proposed typology for PSS and the implementation approach are presented in section 4 , followed by the conclusion and references in the sections 5 and 6 , respectively.

\section{Research methods}

In order to achieve the objectives of this work, a combination of two research approaches was applied to gathering data. Firstly, a brief literature review on ProductService Systems types was performed. This was followed by an analysis of available examples on PSS published in the literature. The literature included journal articles, conference proceedings, theses, and articles in trade journals published from 2003 to 2011. The search strategy identified key words associated with PSS and Life Cycle Engineering, e.g. PSS, servitization, Industrial Product-Service Systems (IPS2), service design, and others.

Some examples on Product-Service Systems were identified and analyzed. The analysis focused on service characteristics and their connection to products, providing insights for the specification of PSS types. Based on data gathered from the examples, an inductive approach was 
adopted to propose a PSS typology. In addition, a deductive approach based on literature review was applied to define the necessary steps to implement PSS.

In order to create a typology of the different possible Product-Service Systems, various phases of analysis had to be completed. After generating a definition of PSS, examples on PSS were identified. A selection of valuable examples was made. Detailed information on the selected examples was gathered and each example was systematized using a reference model (template) of relevant information. Finally, a PSS typology was defined applying an inductive approach.

Each example on PSS was systematized with regard to different characteristics of both product and service: description, frequency, pricing, and key capabilities needed. Moreover, the origin (product or service) and the current importance to fulfill the customer's needs (current PSS weight) were analyzed. Figure 1 illustrates the template used to systematize information gathered on each example.

\section{Literature review}

A Product-Service System (PSS) can be defined as "[...] an integrated combination of products and services." (BAINES et al., 2007, p. 1543) to be "[...] jointly capable of fulfilling specific customer needs." (COOK; BHAMRA; LEMON, 2006, p. 1456). Selling the use is more emphasized than selling the product itself. Thus the products provide technical functions for the consumer (AURICH; MANNWEILER; SCHWEITZER, 2010), while the services ensure the availability of these functions (MAUSSANG; ZWOLINSKI; BRISSAUD, 2009).

Additionally, some authors see PSS as an instrument to achieve more sustainability and reduce pollution of the environment. Rocchi (2005) suggests that a PSS contains "the consumption of environmental resources". Manzini and Vezzoli (2003) also see a "life cycle perspective" in PSS. Previous authors propose that the integrated solution that is achieved by creating a PSS does not only improve the segment of a single stakeholder, but enlarges the ecoefficiency gains of the whole life cycle.

Goedkoop et al. (1999) defined in Baines et al. (2007) the individual elements of PSS:

- Product: a tangible commodity manufactured to be sold.

- Service: an activity (work) done for others with an economic value and often done on a commercial basis.

- System: a collection of elements including their relations.

To understanding the meaning of PSS, the differences and similarities of products and services should be considered. The products provide technical functions for the

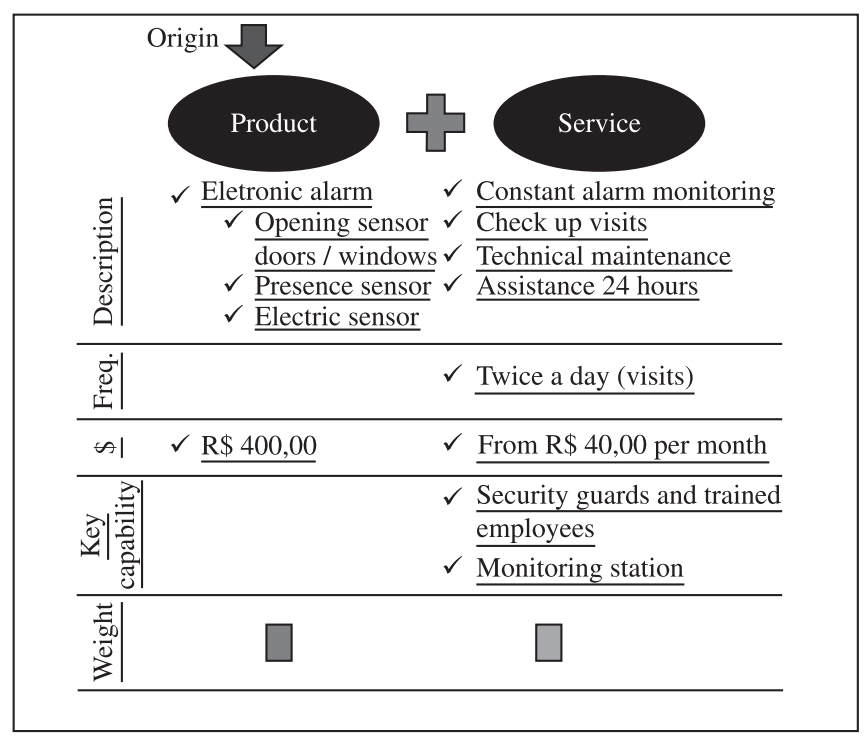

Figure 1. Template for case data collection.

consumer (AURICH; MANNWEILER; SCHWEITZER, 2010), while the services ensure the availability of these functions (MAUSSANG; ZWOLINSKI; BRISSAUD, 2009). However, with today's progress in technologies, the line drawn between products and services is fading (ROCCHI, 2005). Organizations started changing strategically from the sale of products to provision of services (OLIVA; KALLENBERG, 2003; SUNDIN, 2009), a trend which aims to add value to the business (PING; JIA, 2010). Consequently, more companies are opting for solutions which involve services.

The concepts in which services are distinguished from products are tangibility, transfer of ownership, time of generation and consumption, participation of the user, and quality of relationship between producer and user. This means that the producer of a product is not capable of adapting the product in regard to customer wishes after finishing the production while the provider of a service can respond to wishes even during the service delivery. As a consequence, users have different expectations concerning products or services. The effects of these distinct characteristics are that products and services cannot be sold in the same manner. Therefore, the PSS actual composition of product and service determines the way of implementing and also selling it (BAINES et al., 2007; MEIER; ROY; SELIGER, 2008; TUKKER, 2004).

Due to a large number of possible combinations of products and services, different customer needs that have to be fulfilled, and varying goals of Product-Service Systems, different types of PSS are defined in literature. Thus, there is a convergence (Figure 2) of the pure product to the pure service, which is offered in a unique offer, the PSS (TUKKER, 2004). 


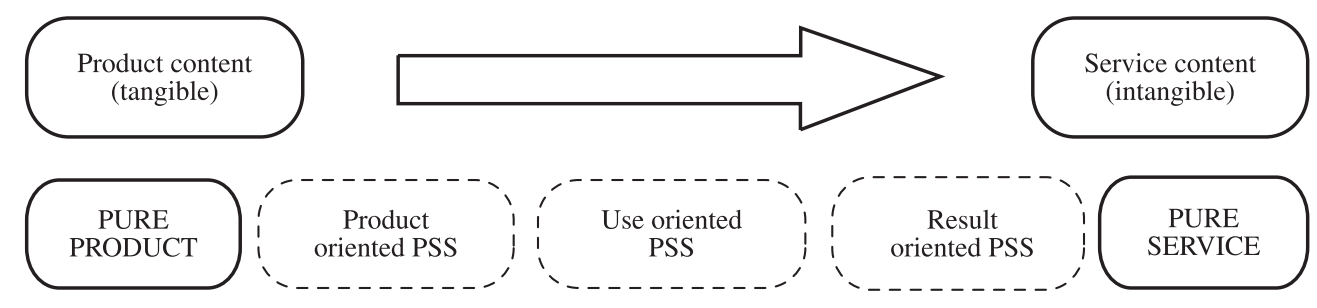

Figure 2. Main categories of the PSS (TUKKER, 2004).

\subsection{PSS types}

Most authors divide Product-Service Systems into three different types or main categories (BAINES et al., 2007, COOK; BHAMRA; LEMON, 2006, TUKKER, 2004; YANG et al., 2009; DURUGBO; TIWARI; ALCOCK, 2011): product-oriented, use-oriented, and result-oriented (Figure 1). These three types can be seen as a continuum with pure product on the one end and pure service on the other end. Different types are located between these extremes with diverse compositions. The convergence of the pure product to the pure service aims to reduce the environmental impact caused by the intensive consumption of tangible products by dematerializing the use of materials. This convergence aims also satisfy continuously the needs of stakeholders through personalized services.

The product-oriented Product-Service System features the sale of products with additional services. The ownership rights are transferred to the costumer. Typical services are maintenance and upgrade. This type is easier to implement, but generally, environmental benefits can only be achieved incrementally. In the use-oriented PSS, the product ownership rights remain at the service provider, while the customer purchases the use or the availability of the product over a specific period of time or units. The provider is interested in high usage along with a reduction of the amount of products. In this case, greater environmental benefits are expected. A result-oriented PSS describes the sale of a service or capability instead of the sale of the product. The product itself may not be easily identified and the ownership rights are retained by the service provider. Risks are taken over by the provider and the costumer loses power over means, but this PSS type implies new ways of function fulfillment.

The distinction of PSS types by Tukker (2004) has been refined by other authors, e.g. Aurich, Mannweiler and Schweitzer (2010) and Fan and Zhang (2010) by using a more subdivided classification of Product-Service System types or proposing a novel denomination of the types. The different classifications have in common that there is a distinction between selling the product itself with additional services to a greater or lesser extent and providing the desired service without transfer of ownership.

\subsection{PSS implementation}

When planning PSS, the company needs to change from the "product thinking" to the "system thinking" which focuses on the use of the product (LEE; ABUALI, 2010). Thus, PSS have to be developed and implemented on a case-by-case basis because of their high complexity and diversity (BAINES et al., 2007). Despite this circumstance, literature offers some frameworks with steps or phases on implementation of Product-Service Systems. Most frameworks comprise three to seven steps or phases that have to be accomplished for the implementation. The steps are accurately described including the used tools and activities (ROCCHI, 2005) or only stated as a short guide without further description (YANG et al., 2009).

The majority of the proposals values the fulfillment of customer requirements and therefore begins with the analysis of the needs to be fulfilled by the PSS. This is followed by the concrete design of the product and the corresponding services, and the actual realization of the product and services combined. The implementation of a PSS is completed with its evaluation and improvement.

In order to compare different perspectives from the literature, four approaches are presented in Table 1. It shows the amount of steps/phases of each approach. Moreover, Table 1 describes the activities which should be performed, grouped in the three categories "Preparation", "Implementation/Realization", and "Measurement of results". In each column, the steps or phases that are described in the approaches of Rocchi (2005), Yang et al. (2009), Calminder and Carlshamre (2008), and Morelli (2003) are displayed. Rocchi (2005) and Morelli (2003) illustrate a detailed framework with precise descriptions of actions and tools, while the other frameworks consist of three steps. The proposals from of Rocchi (2005), Calminder and Carlshamre (2008), and Morelli (2003) start with the development of new ideas and the analysis of the market, whereas the phases of Yang et al., (2009) refer to cases with data already being available.

Having outlined the literature on PSS attention is turned to the proposal of this paper. 
Table 1. PSS Implementation types.

\begin{tabular}{|c|c|c|c|c|}
\hline Author & Rocchi (2005) & Yang et al. (2009) & $\begin{array}{c}\text { Calminder and } \\
\text { Carlshamre (2008) }\end{array}$ & Morelli (2003) \\
\hline Amount of steps/phases & 6 & 3 & 3 & 7 \\
\hline Preparation & $\begin{array}{l}\text {-Exploration } \\
\text {-Policy formulation } \\
\text {-Idea finding }\end{array}$ & $\begin{array}{l}\text {-Design Intelligent Data } \\
\text { Units (IDUs) and embed } \\
\text { into products }\end{array}$ & $\begin{array}{c}\text {-Analyzing (internal and } \\
\text { external) } \\
\text {-Creating and detailing } \\
\text { new ideas }\end{array}$ & $\begin{array}{l}\text {-Definition of needs to be } \\
\text { fulfilled } \\
\text {-Market analysis } \\
\text {-Architecture and main } \\
\text { functionality of PSS }\end{array}$ \\
\hline $\begin{array}{l}\text { Implementation/ } \\
\text { realization }\end{array}$ & $\begin{array}{c}\text {-Strict development } \\
\text { (Design) } \\
\text {-Realization }\end{array}$ & -Develop service enabler & $\begin{array}{l}\text {-Realization of the } \\
\text { detailed concept }\end{array}$ & $\begin{array}{c}\text {-Use-case analysis } \\
\text {-Tentative architecture } \\
\text {-Test } \\
\text {-Final definition }\end{array}$ \\
\hline Measurement of results & -Evaluation & $\begin{array}{c}\text {-Transmit data to service } \\
\text { enabler }\end{array}$ & $\begin{array}{l}\text {-Evaluation included in } \\
\text { "realization" }\end{array}$ & - \\
\hline
\end{tabular}

\section{Results and discussion}

This section presents the PSS definition considered in this research, the proposed typology of PSS as well as the proposed PSS implementation approach.

\subsection{Product-Service System definition and criteria}

Primarily, a clear definition of PSS, to be used in the identification of practical examples, needed to be drawn. The definitions found in the literature research focus mostly on providing a general concept of PSS. The aim of the proposed definition is to enable, through a set of criteria, the specification of whether a determined case can be classified as a PSS.

Based on the analysis of practical examples, three essential criteria to define an actual PSS could be identified:

- Co-existence of physical product and provided service: It is necessary to highlight that in a ProductService System the co-existence of physical product and service should be explicit.

- Possibility to generate recurring revenues: In Product-Service Systems, it should be possible for the provider to create recurring revenue streams to complement or to totally replace an all-at-once payment.

- Continuity of service provided: As one of the aims of a PSS is to create a lasting relationship between customer and PSS provider, the continuity of the provided service is also defined as critical requirement. As a result, examples in which the service is limited to a simple onetime relationship (e.g. product delivery to customer site) may not be considered a PSS.

Besides the three requirements defined earlier, it is important to call the attention to another characteristic that is observed in most PSS examples: the definition of more sustainable business models. Whereas sustainability is a desired characteristic of PSS, it is not prerequisite itself, as some examples which fulfill the three defined criteria above do not automatically lead to reduction on environmental impact. In fact, the sustainability issue is not consensus in the PSS literature. Based on these criteria, it was possible to select PSS examples as a basis to propose the new PSS typology.

\subsection{Examples of PSS}

As mentioned in section 2, some examples on ProductService Systems were identified and analyzed. A brief description of each example follows.

\subsubsection{Example 1 - Brastemp - water filter}

In this case, the product is a water filter and the service is the maintenance of the product, resulting in continuous provision of filtered water for the customer. The property of the water filter is not transferred to the customer. Pricing model considers no upfront payment and a monthly fee which encompasses the use of the product and its maintenance, including all necessary parts. The company determines the correct destination of products, which are $99 \%$ recyclable. The origin was the product, as it is provided by a typical white goods industry player. This case was classified as "Continuous product use without property, including maintenance".

\subsubsection{Example 2 - Gispen - office furnishing}

Gispen provides business office furniture in a PSS model. Product property is also not transferred to the customer. The product core is the furniture. A range of services includes consulting on the office's design and space allocation, furniture maintenance and all necessary updates, as customer needs evolve. It was originated as a pure-product. Compared to Example 1, the main differences are breadth and depth of services provided, leading to the definition of another type called "Continues product use without property, including broad and high value-added services". 


\subsubsection{Example 3 - Electrolux - pay per use wash machine}

This example refers to a pilot of PSS created by Electrolux. The product is the washing machine and the service is the use of the machine. The customer does not own the property of the washing machine, but instead possesses the machine and pays according to how much it is used. The main difference to Example 1 (water filter) is that the pricing does not include continuous product use through a monthly fee. The customer actually pays per machine use (washed clothes), which in turn requires specific technology for machine monitoring and capabilities for variable charges according to specific use. This case was originated from a product manufactured and can be classified as "Pay per use".

\subsubsection{Example 4 - ENG - Strollers}

This trade was developed with a function of high cost for the customers who use the product for an average period of 12 months. The strollers are designed for remanufacturing and the consumer buys the function of them, using only during the time determined by them (MONT; TUKKER, 2006). As already stressed, besides obtaining economic gains, PSS solutions should contribute to the reduction of the environmental impact caused by the consumption and provide a better social balance.

\subsubsection{Example 5 - Sekisui Chemical C0.,LID (Japão) - house reutilization}

The company reuses modular houses. When old houses are no longer used they are disassembled, inspected and repaired to be used again (KANG; WIMMER, 2008). Using this system, about $85 \%$ of the original house is reutilized resulting in waste reduction. This contributes not only to end the cycle of materials but also to create a new value from the resources that are reutilized.

\subsection{Proposed typology}

The proposed typology describes the possibility to combine products and specific services, forming different Product-Service System types. PSS are divided in two main groups: durable goods (upper part of Figure 3) and capital goods (lower part of Figure 3). Within these groups, more specific types were defined, each one including one or more services correlated with the particular product.

It is important to highlight that in the selection of the examples, it was not possible to find examples for nondurable goods which would have been a third group. In general, these products, when combined with a service, do not fulfill the prerequisite that refers to continuity of service provided, due to the lack of durability even for the pureproduct itself. The resulting typology is pictured in Figure 3.

The typology in Figure 3 was created in an attempt to facilitate the classification of a Product-Service System and thereby be a basis to support the definition of new PSS. An existing product can be matched to one of the product groups and then combined with one of the possible services. In contrast to the common distinction between productoriented, use-oriented, and result-oriented Product-Service System types, the distinction used for this typology should be more beneficial for the process of creating a PSS. The common distinction is useful for classifying an existing Product-Service System according to the main component, being either the product or the service. Various types of Product-Service Systems can be implemented using the following general implementation approach for PSS.
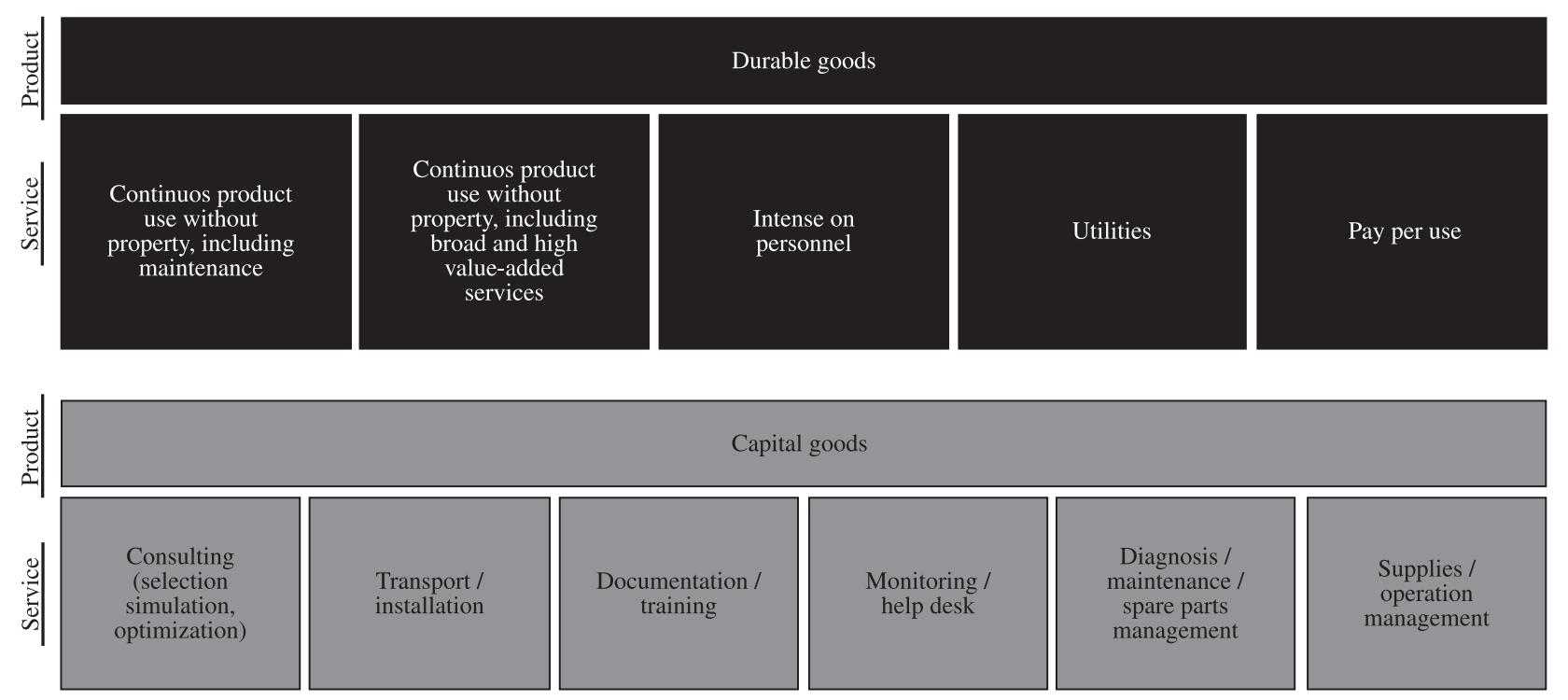

Figure 3. Product-Service System types. 


\subsection{PSS implementation approach}

Product-Service Systems are very specific because of the great diversity of possible combinations of products with services. Literature has not produced a common and uniform way of implementing a PSS yet. All implementation models consist of several steps including generally a preparation and a realization phase, and some are complemented with an evaluation phase, as discussed in section 3 .

The preliminary implementation approach proposed combines different authors' perspectives from literature research, but also includes relevant actions or tools identified in the examples provided. The designed typology of Product-Services Systems was used as a basis and the implementation approach is supposed to fit all PSS types. The goal of this approach was to make the implementation of different Product-Service Systems practicable. Before starting the implementation of a PSS itself, it is necessary to conduct specific analyses to prioritize alternatives and map capability gaps. In this first phase, expected results include a list of prioritized services, the business model definition, and identification of process and capability gaps. The company should reach a conclusion about PSS viability and next steps to implement it.

The second phase consists of the actual implementation. It is necessary to carry out a series of tasks in order to consolidate all already existing services. Finally, an expansion of services is to be performed based on the study of possibilities made in the previous step.

The two phases of implementation are:

- Analyses/Diagnosis: This phase consists of the following steps to verify the feasibility of PSS:

- Screening and prioritization: analysis of the companies' value chain and identification of possible service trends that can increase the success.

- Conceptual design: includes the development of use cases, the business model specification and the requirements identification.

- Gaps analysis: check of the currently existing services (if there are any) to identify gaps for further services and decision if the PSS should be further deployed.

- Implementation: wherein this phase, the implementation will be performed in fact, based on analysis in the previous phase. The following actions should be performed:

- Services consolidation: specific organizational structure should be created to manage services. In addition, PSS goals should be defined.

- Services expansion: This includes all services: current, basic, and advanced.

\section{Concluding remarks}

A typology of Product-Service Systems and an implementation approach for PSS have been proposed. The typology considers two product groups - durable goods and capital goods - and their possible combinations with various service types, hence Product-Service System types. Some of those PSS types are illustrated by the examples. The implementation approach for PSSs is a guideline to facilitate the process of creating new Product-Service Systems for product based manufacturing companies. The proposed approach consists of two phases, divided into a total of five steps, in order to implement the different types of PSS. Obviously, this proposal should be further developed. Next research steps and suggestion for future research include the progress of this proposal.

\section{Acknowledgments}

The authors thank to Axia Value Chain for funding the research, the DAAD (German Academic Exchange Service) for a RISE scholarship, CAPES and CNPq for funding some authors.

\section{References}

AURICH, J. C.; MANNWEILER, C.; SCHWEITZER, E. How to design and offer services successfully. CIRP Journal of Manufacturing Science and Technology, v. 2, n. 3, p. 136-142, 2010. http://dx.doi.org/10.1016/j. cirpj.2010.03.002

BAINES, T. S. et al. State-of-the-art in product-service systems. Proceedings of the Institution of Mechanical Engineers, Part B: Journal of Engineering Manufacture, v. 221, n. 10, p. 1543-1552, 2007. http://dx.doi. org/10.1243/09544054JEM858

CALMINDER, T.; CARLSHAMRE, M. The Transition To Product-Service Systems - A Business Development Method for Small and Medium-Sized Manufacturing Enterprises. 2008. Tese (Doutorado)-Department of Management and Engineering, Division of Industrial Marketing, Linköping, 2008.

COOK, M. B.; BHAMRA, T. A.; LEMON, M. The transfer and application of Product Service Systems: from academia to UK manufacturing firms. Journal of Cleaner Production, v. 14, n. 17, p. 1455-1465, 2006. http://dx.doi.org/10.1016/j. jclepro.2006.01.018

DURUGBO, C.; TIWARI, A.; ALCOCK, J. R. A review of information flow diagrammatic models for productservice systems. The International Journal of Advanced Manufacturing Technology, v. 52, n. 9-12, p. 1193-1208, 2011. http://dx.doi.org/10.1007/s00170010-2765-5 
FAN, X.; ZHANG, H. Aligning Product-Service Systems with Market Force. In: INTERNATIONAL CONFERENCE ON SERVICE SCIENCE, 2010, Hangzhou. Proceedings... IEEE, 2010. p. 110-114. http://dx.doi.org/10.1109/ ICSS.2010.59

GOEDKOOP, M. J. et al. Product Service Systems, ecological and economic basics. Report for Dutch Ministries of Environment (VROM) and Economic Affairs (EZ), 1999.

KANG, M. J.; WIMMER, R. Product service systems as systemic cures for obese consumption and production. Journal of Cleaner Production, v. 16, n. 11, p. 1146-1152, 2008. http://dx.doi.org/10.1016/j.jclepro.2007.08.009

LEE, J.; ABUALI, M. Innovative Product Advanced Service Systems (I-PASS): methodology, tools, and applications for dominant service design. The International Journal of Advanced Manufacturing Technology, v. 52, n. 9-12, p.1161-1173, 2010. http://dx.doi.org/10.1007/s00170-0102763-7

MANZINI, A.; VEZZOLI, C. A strategic design approach to develop sustainable product service systems: examples taken from the 'environmentally friendly innovation' Italian prize. Journal of Cleaner Production, v. 11, n. 8, p. 851-857, 2003. http://dx.doi.org/10.1016/S09596526(02)00153-1

MAUSSANG, N.; ZWOLINSKI, P.; BRISSAUD, D. Product-service system design methodology: from the PSS architecture design to the products specifications. Journal of Engineering Design, v. 20, n. 4, p. 349-366, 2009. http://dx.doi.org/10.1080/09544820903149313

MEIER, H.; ROY, R.; SELIGER, G. Industrial Product-Service Systems - IPS ${ }^{2}$. CIRPAnnals Manufacturing Technology, p. 1-24, 2008.

MONT, O.; TUKKER, A. Product-Service Systems: reviewing achievements and refining the research agenda. Journal of Cleaner Production, v. 14, n. 17, p. 1451-1454, 2006. http://dx.doi.org/10.1016/j.jclepro.2006.01.017
MORELLI, N. Product-service systems, a perspective shift for designers: A case study: the design of a telecentre. Design Studies, v. 24, n. 1, p. 73-99, 2003. http://dx.doi. org/10.1016/S0142-694X(02)00029-7

OLIVA, R.; KALLENBERG, R. Managing the Transition from Products to Services. International Journal of Service Industry Management, v. 14, n. 2, p. 160-172, 2003. http:// dx.doi.org/10.1108/09564230310474138

PING, W. L.; JIA, F. Analysis on Supply Chain of Manufacturing Enterprise Product Service System. In: EMERGENCY MANAGEMENT AND MANAGEMENT SCIENCES - ICEMMS, IEEE INTERNATIONAL CONFERENCE, 2010. Proceedings... IEEE, 2010. p. 126-129.

ROCCHI, S. Enhancing Sustainable Innovation by Design. 2005. Tese (Doutorado)-Erasmus University Rotterdam Rotterdam, 2005.

SAKAO, T.; SANDSTRÖM, G. Ö.; MATZEN, D. Framing research for service orientation of manufacturers through PSS approaches. Journal of Manufacturing Technology Management, v. 20, n. 5, p. 754-778, 2009.

SUNDIN, E. Life-Cycle Perspectives of Product/ServiceSystems: In: SAKAO, T.; LINDAHL, M. (Eds.). Introduction Design Theory to Product/Service-System Design. London: Springer, 2009. p. 31-49. http://dx.doi. org/10.1007/978-1-84882-909-1_2

TUKKER, A. Eight types of product-service system: eight ways to sustainability? Experiences from suspronet. Business Strategy and the Environment, v. 13, n. 4, p. 246-260, 2004. http://dx.doi.org/10.1002/bse.414

YANG, X. et al. A practical methodology for realizing product service systems for consumer products. Computers \& Industrial Engineering, v. 56, n. 1, p. 224-235, 2009. http://dx.doi.org/10.1016/j.cie.2008.05.008 
